\title{
Analysis of Community Empowerment in the Implementation of Healthy Living Movement Programs (GERMAS) in the Regional Post-Disaster Palu City
}

\author{
Ardiansyah Arif ${ }^{1}$, Muhammad Syafar $^{2}$, Erniwati Ibrahim ${ }^{3}$, Suriah $^{4}$, Anwar Mallongi $^{5}$, Muhammad Alwy $^{6}$ \\ ${ }^{I}$ Student Master Program, Department of Health Promotion and Behavioral Sciences, Faculty of Public Health, \\ Universitas Hasanuddin, ${ }^{2}$ Professor, Department of Health Promotion and Behavioral Sciences Faculty of Public \\ Health, Universitas Hasanuddin, ${ }^{3}$ Lecturer, Department of Environmental Health, Faculty of Public Health, \\ Universitas Hasanuddin, ${ }^{4}$ Lecturer, Department of Health Promotion and Behavioral Sciences Faculty of Public \\ Health, Universitas Hasanuddin, ${ }^{5}$ Professor, Department of Environmental Health, Faculty of Public Health, \\ Universitas Hasanuddin, ${ }^{6}$ Lecturer, Department of Health Policy Administration, Faculty of Public Health, \\ Universitas Hasanuddin
}

\begin{abstract}
Community empowerment is one of the global strategies for health promotion so that community empowerment is very important to do so that the community as the primary target has the will and ability to maintain and improve health. The Healthy Living Community Movement Program (GERMAS) is basically a public health effort through community empowerment. This study aims to analyze the process of community empowerment in the implementation of the Healthy Living Community Movement Program (GERMAS) in post-disaster areas. This type of research is qualitative using a phenomenological study approach. Data collection is done by in-depth interviews, document review, FGD (Focus Group Discussion), and documentation. The results showed that the implementation of community empowerment in the Healthy Living Community Movement Program (GERMAS) by conducting integrated collaboration with related sectors such as Empowerment of Family Welfare (PKK), National Narcotics Agency (BNN), Ministry of Religion, Office of Women's Empowerment and Child Protection and banking. Incentives for health cadres are budgeted by the Health Office of the City of Palu in the amount of Rp. 150,000 (one hundred and fifty thousand Rupiah) per quarter. It was concluded that community empowerment in the implementation of GERMAS in the post-disaster area of Balaroa Village was in the aspect of partnerships in the form of cooperation with various cross-sectors in that program, integration of GERMAS with other priority programs such as GALI GASA, coordination with all stakeholders by involving community leaders, youth leaders, and the $\mathrm{K} 5$ task force. From the aspect of the budget in the form of budget allocation in every financing activities of the program and providing incentives for cadres. From the aspect of evaluating activities in the form of a final report on activities, the residents have cultivated vegetables and other plants in their own yards.
\end{abstract}

Keywords: Community Empowerment, Germas, post-disaster.

\section{Introduction}

The condition of public health in Indonesia is

\section{Corresponding Author:}

\section{Ardiansyah Arif}

Student Master Program, Department of Health

Promotion and Behavioral Sciences, Faculty of Public

Health, Universitas Hasanuddin

e-mail: ardiansyaharif2015@gmail.com currently experiencing major challenges namely the three burden of disease (triple burden) because there are still infectious diseases, increasing noncommunicable diseases (PTM) and diseases that should have disappeared again. The country of Indonesia faces changes in disease patterns or what is often called the epidemiological transition in the last 30 years. The biggest causes of death and illness in the 1990s were infectious diseases such as upper respiratory infections (ARI), TB, diarrhea, etc. ${ }^{1}$ 
There are many health problems in general that occur in Indonesia, especially in the city of Palu, which has experienced natural disasters due to the earthquake, tsunami, and liquefaction on 28 September 2018. Palu City which is the center of government and economic heart of Central Sulawesi Province affected by the disaster recorded 1,649 people died, 2,549 people were injured, 265 were missing and 152 were estimated to be buried and have not been evacuated due to the incident. This caused the paralysis of Palu City from various aspects, there were around 62,359 inhabitants in refugee camps, 66,926 houses were thought to be damaged ${ }^{2}$

Various problems especially in the health sector that arise at this time actually do not need to occur if the community plays an active role in accordance with their respective roles ranging from awareness of maintaining personal health, family, environment, health program planning and supervision. The Healthy Life Community Movement Program (GERMAS) launched by the government through Presidential Instruction No. 1 of 2017 is basically a public health effort through community empowerment. Community empowerment in the health sector is the main target of health promotion. Community empowerment is one of the global strategies for health promotion so that community empowerment is very important to do so that the community as the primary target has the will and ability to maintain and improve health.

At the initial stage, GERMAS began with a focus on three activities, namely carrying out 30 minutes of physical activity every day, consuming vegetables and fruit and regular health checks at least once every 6 (six) months as an early detection effort disease. These three activities can be started by yourself and your family.

Thus an analysis of community empowerment is needed in the implementation of GERMAS in the postdisaster area of Palu City. This study aims to analyze community empowerment in the implementation of GERMAS in the post-disaster area of Palu City.

\section{Material and Method}

This type of research is qualitative using a phenomenological study approach. A sampling of informants was carried out using a purposive sampling technique, namely determining the sample of research informants by means of deliberately selecting or appointing them to be informants. The subjects used as informants in this study were 10 (ten) people. The method in collecting data in this research is in-depth interviews, Focus Group Discussion (FGD), documentation.

Data obtained through in-depth interviews in this study were analyzed using content analysis. Content analysis involves a process designed to condense raw data into categories or themes based on valid conclusions and interpretations. The process of content analysis in qualitative research begins with data collection, to support the drawing of valid and reliable conclusions, the reduction of data tailored to the objectives of the study.

\section{Results}

Empowerment Stage: The results of research on community empowerment related to the analysis of the power supply stage can be listened to through the following in-depth interviews with informants:

Research questions about how to analyze the steps of the Power Giving Phase related to partnerships in the implementation of GERMAS in post-disaster areas in Balaroa Village?

“... During this time we are collaborating with the GALI GASA program, the K5 task force, PKK, BNN, including the Ministry of Religion, women empowerment, child protection, banking assistance, GERMAS is integrated with other parties ..."

“... Sinceweentered the emergency response, the postdisaster period, the transition period, the reconstruction and recovery period, we have done everything, besides GERMAS, there are also special treatments, health services, and reproductive health posts. So post 24-hour public health during the emergency response period. We cannot work alone because of limited manpower so that after the disaster many parties involved were involved there but continued to coordinate with the puskesmas because of our work area. "

Research questions on how to analyze the steps for the Empowerment Phase in relation to budget support in implementing GERMAS in the post-disaster area of Balaroa Village?

“... In 2020 , which is usually 50 people/village to 100 people/village. Last year needed 3 tents, now it needs 6 tents. Funding from the Regional Budget ... “

"... What is important is that if there is a listing of the director, there is a hook in the RPJMD, then every 
year the budget will come out. The allocation last year was quite large because of the activities almost every week ... “

The excerpts from the interview results above explain that the budget support for GERMAS in the Palu City Health Office has increased but is not significant from previous years, where there are an increase of 2 (two) times the financing volume of 50 people every village to 100 people every village, from the needs of 3 (three) tents to 6 (six) tents. This is reinforced by the explanation of the Regional Development Planning Agency (BAPPEDA) of Palu City that the budget allocation for GERMAS is annually and is quite large.

Related to research questions about incentives for cadres in the implementation of GERMAS in the postdisaster area of Balaroa Village?

“... If from BOK 50 thousand/month. I have been given incentives starting from my work in 2011. Received quarterly .. “

“.. Cadre incentives from our government, a month of 50,000 are received per quarter. So the officers here take the funds in the new service, we are here to channel ..."

From the interview excerpt above that up to now the incentive for health cadres in Balaroa Village is budgeted by the Palu City Health Office and then distributed by Sangurara Health Center every quarter of Rp. 150,000 (one hundred and fifty thousand Rupiah) every quarter.

Related to research questions regarding the evaluation of the implementation of GERMAS in the post-disaster area of Balaroa Village?

“... Activity reports start from Integrated healthcare center (posyiandu) cadres, village health post (poskesdes), community leaders. Usually every month it comes on every 5th. In 2019 there are already independently formed community groups, there are daily activities related to GERMAS. A group of about 4-5 groups emerged in West Palu. “

“... Yesterday before the earthquake, the community had planted cayenne pepper, vegetables in their respective homes, seeds from the Agriculture Service. Traditional birth attendants is given socialization so that they will no longer give birth at home. Still, they can but are accompanied ..."
The interview excerpt above explained that the evaluation of the implementation of GERMAS was reported in the form of reports byIntegrated healthcare center(posyiandu)cadres, village health post (poskesdes) and community leaders who were completed in the public health center (puskesmas) report. In addition, around 4-5 community groups have been formed which independently carry out activities related to GERMAS without any intervention from the local government, community awareness to conduct clean and healthy lifestyles is better, formed Community-Based Health Efforts (UKBM), and before the disaster, residents had already grown vegetables and chilies in their own yards.

\section{Discussion}

Community empowerment in the health sector is more aimed at increasing community participation in the health sector. Community participation is the activity of involving the community in a program. It is expected that with high community participation, a health program can be more targeted and have greater leverage for behavior change because it can create a value in the community that the health activities are from us and for us ${ }^{3}$

Community empowerment is an effort or process to foster awareness, willingness and ability of the community to recognize, overcome, maintain, protect, and improve their own welfare. Community empowerment in the health sector is an effort or process to foster awareness of the willingness, and ability to maintain and improve health ${ }^{4}$

The Healthy Life Community Movement Program (GERMAS) is a systematic and planned action taken jointly by all components of the nation with awareness, willingness, and ability to behave in a healthy manner to improve the quality of life. GERMAS can be done by doing physical activities, consuming vegetables and fruits, not smoking, not consuming alcohol, checking health regularly, cleaning the environment, and using the toilet ${ }^{5}$

Based on the results of research on the analysis of community empowerment in implementation GERMAS conducted in Balaroa Village, Palu City, shows a picture of the implementation of community empowerment through stages. The discussion of these stages is described as follows:

Empowerment Stage: The stage of giving power itself or empowerment. At this stage, the authority is 
given to identify the problem and the right strategy to overcome the problem of community empowerment in implementing GERMAS. Community empowerment activities at this stage appear in the form of partnerships, utilization of potential and resources, integration of activity programs and evaluations in the implementation of the GERMAS.

Explore and develop the potential of each community member so that they can contribute according to their ability to jointly planned programs or activities Community contribution is a form of community participation in the form of energy, thoughts or ideas, funds, building materials, and other facilities to support health businesses.

According to Sari and Sulistiowati, the tasks of the public health center (puskesmas) are so numerous and not possible to be done by the public health center (puskesmas) themselves, it needs support from various parties. A partnership is one of the important health promotion strategies to be implemented, which must begin with the identification of community leaders in order to form a tiered and sustainable partnership. The implementation of GERMAS in all villages in the city of Palu is integrated with the Gali Gasa Program which is also a priority and priority program in the city of Palu. ${ }^{6}$

In addition, the provision of incentives for health cadres in every community empowerment activity related to GERMAS carried out in Balaroa Village has been carried out by the Palu City Health Office through the Sangurara Health Center by providing incentives of Rp. 150,000/quarterly. According to the research results of Bhattacharayya et al., 2001, giving awards in the form of cash to cadres does have an advantage. The advantage of money as a cadre incentive can be asked to work longer hours to achieve certain goals, supervision can be carried out strictly so that the program can be implemented quickly, regular work routines and service quality can be maintained, negative reinforcers such as dismissal or punishment that can be used to encourage desired performance and payments are also seen as helping to build economic equality in populations that lack economies. In line with this, the WHO (World Health Organization) sees the need for cadre payments as a long-term program sustainability effort ${ }^{7}$

Even so, the provision of incentives in the form of cash causes a weak sense of volunteerism from cadres. Wirapuspita revealed that monetary incentives can improve the performance of cadres, but the incentive management system by the government can reduce the voluntary nature of cadres and weaken community empowerment $^{8}$. Bhattacharyya et al., incentives in the form of money have losses, which can lead to jealousy and hostility if not all CHWs (Community Health Workers) or other communities that work are paid, thereby damaging their commitment and their relationship with the community, CHWs (Community Health Workers) those who receive salary or wages can see themselves as government employees or NGOs rather than as community servants ${ }^{9}$

Based on the results of the study, it is important for posyandu managers and coaches, both at the village office, sub-district, public health center (puskesmas), health offices and city government levels to consider giving and managing money incentives to cadres, so that the provision of incentives can be on target and the desired goals can be achieved.

\section{Conclusion}

At the power supply stage in the implementation of the Healthy Life Community Movement Program (GERMAS) in the post-disaster area of Balaroa Village in the aspect of partnerships in the form of collaboration with various cross-sectors, integration with other priority programs such as GALI GASA, coordination with all stakeholders involving community leaders, youth leaders, and K5 task force. From the aspects of the budget in the form of budget allocation in every financing activities of the Healthy Living Movement Program (GERMAS) and providing incentives for cadres. From the evaluation aspect of the activity in the form of a final report on the activities of the Healthy Living Community Movement Program (GERMAS) that has been carried out, the residents of Balaroa Village have been cultivating vegetables and other plants in their respective yards.

\section{Conflicts of Interest: None}

Source of Funds: Self

Ethical Clearance: Health Research Ethics Committee, Faculty of Public Health, Universitas Hasanuddin.

\section{References}

1. Kuswenda D.Joint Action Conducting Healthy Living Movement. Jakarta: Kementerian Kesehatan 
RI;2017

2. Badan Nasional PenanggulanBencana [Internet]. Jakarta: Badan Nasional PenanggulanBencana; 2018. Tsunami Terjang Palu; updated 2018 September 28; cited 2019 November 17]; [about 4 screens] .Available from: https//www.bnpb.go.id/ tsunami terjang palu

3. Notoatmodjo S. Health Promotion and Health Behavior. Jakarta: Rineka Cipta; 2010.

4. Supardan I. Pemberdayaan Masyarakat Bidang Kesehatan [Internet]. [updated 2013; cited 2019 October 11].

5. Kementerian Kesehatan Republik Indonesia. Buku Panduan GermasBukudan Media Lainnya [Internet]. Jakarta; 2017 [cited 17 November 2019] Available from: http://promkes.kemkes.go.id/dl/ panduan_germas.pdf

6. Sari, I I K, Sulistiowati M. Analisis Promosi Kesehatan di Puskesmas Kalijudan Terhadap PHBS Ibu Hamil. Jurnal Promkes The Indonesian Journal of Health Promotion and Health Education.2015;3(2).

7. WHO, PEPFAR, \& UNAIDS. Task Shift ing: Rational Redistribution of Task Among Health Workforce Teams. Global Recommendationsand Guidelines. Geneva: The World Health Organization; 2007.

8. Wirapuspita W R.InsentifUangTunai dan Peningkatan Kinerja Kader Posyandu. Jurnal Kesehatan Masyarakat Nasional. 2012;7(1):44-48

9. Bhattacharyya K, Winch P, Leban K, \& TienM. Community Health Worker Incentives and Disincentives: How They Affect Motivation,
Retention, and Sustainability. Virginia: Basic Support for Institutionalizing Child Survival Project (BASICS II) for the United States Agency for International Development; 2001

10. Eka sulistyawaty, Syafar, M., Daud, A., ArsunanArsin, A., Mallongi, A., Werdyaningsih, E. Change of behavior of ODF through STBM Program in CempakaPutih Village North Gorontalo Regency, EnfermeriaClinicaVolume 30, June 2020, Pages 396-398

11. Muhith A, Winarti E, Perdana SSI, Haryuni S, Rahayu KIN, Mallongi A. Internal Locus of Control as a Driving Factor of Early Detaction Behavior of Servical Cancer by Inspection Visual of Acetic Acid Method. Open Access Maced J Med Sci. 2020Apr 20; 8(E):113-116. https://doi. org/10.3889/oamjms.2020.4341

12. Anwar Mallongi, Agus Bintara Birawida, RatnaDwiPujiAstuti, Muh Saleh, Effect of lead and cadmium to blood pressure on communities along coastal areas of Makassar, Indonesia. EnfermeríaClínica., Volume 30, Supplement 4, June 2020, Pages 313-317

13. Syamsir, Birawida, A. B., and A. Faisal. "Development of Water Quality Index of Island Wells in Makassar City." In Journal of Physics: Conference Series, vol. 1155, no. 1, p. 012106. IOP Publishing, 2019.

14. Birawida, A. B., M. Selomo, and U. W. Ismita. "Environmental health hazards against bacterial contamination of cutlery on the small island of Makassar.” E \& ES 235.1 (2019): 012023. 